\title{
Thrombocytosis in the Setting of Isomerism and a Functionally Univentricular Heart
}

\author{
Rohit Loomba ${ }^{1}$ \\ 1. Department of Cardiology, Children's Hospital of Wisconsin \\ $\square$ Corresponding author: Rohit Loomba, rloomba@chw.org \\ Disclosures can be found in Additional Information at the end of the article
}

\section{Abstract}

Introduction

Bodily isomerism, also known as heterotaxy, is a unique entity in which there is mirror imagery in various organ systems. Those with isomerism will often have congenital malformations of the heart requiring functionally univentricular palliation. Anecdotally, thrombocytosis has been noted with higher frequency in patients with isomerism. This study aimed to determine the prevalence of thrombocytosis at different stages and identify independent predictors of thrombocytosis.

Methods

We identified patients with isomerism and a functionally univentricular heart who received care at our institution between January 1998 and January 2014. Clinical data regarding these patients was collected via chart review. Platelet counts were collected before initial surgical palliation, the day prior to second surgical palliation, and the day prior to the third surgical palliation. Platelet counts from the first postoperative day following all three surgical palliations was also collected. Mean platelet counts were compared between consecutive stages as well as to the initial platelet count. The frequency of thrombocytosis was also calculated at each point with a binomial logistic regression conducted to determine independent risk factors of thrombocytosis at each time point.

\section{Results}

A total of 57 patients were included in the analysis. The mean platelet count before initial surgical palliation was $349.21 \times 10^{9} / \mathrm{L}$ and decreased with age. Thrombocytosis was noted in $15.8 \%$ prior to initial surgical palliation and $23.6 \%$ prior to second surgical palliation.

Thrombocytosis was no longer noted after second surgical palliation. No independent risk factors for thrombocytosis were identified.

\section{Conclusion}

Thrombocytosis is not infrequent during the first year of life in those with isomerism. It is important to be vigilant of platelet counts in this population as thrombocytosis may lead to increased thromboembolic events, particularly in the setting of a Blalock-Taussig shunt. Thrombocytosis nearly always resolves after the second surgical palliation.

Categories: Cardiology, Pediatrics 
Keywords: thrombocytosis, heterotaxy, isomerism, single ventricle, univentricular, platelet

\section{Introduction}

Bodily isomerism, also referred to as heterotaxy, is a multisystem laterality defect affecting nearly 1 in 10,000 children [1-3]. In the presence of isomerism, there is mirror imagery of the thoracic organs such that there are morphologically left or right bronchi bilaterally as well as morphologically left or right lungs bilaterally. Also noted in the thoracic cavity is isomerism of the atrial appendages. Abnormalities in other organ systems are also present with abnormal lateralization but not isomerism present in the abdominal cavity. Segregated on the basis of atrial appendage morphology into right or left isomerism, those with bodily isomerism (hereafter referred to as simply isomerism) will have a different constellation of findings based on the sidedness of isomerism [4-7]. Congenital malformations of the heart are common with many requiring functionally univentricular palliation. Abnormalities in the cardiac conduction system are also common with subsequent development of arrhythmias [8-10]. Those with isomerism will often have splenic abnormalities, the common presence of multiple spleens in left isomerism and absence of a spleen in right isomerism. Some, however, may have a solitary, normally located spleen. Regardless of splenic anatomy, however, functional asplenia may be present [11]. Although the precise mechanism of this has not been elucidated, it is possible that ciliary dyskinesia may play a role in this.

As a consequence of functional asplenia, those with isomerism are at increased risk for bacteremia, particularly in the first five years of life. Children with isomerism and functionally univentricular hearts have also been demonstrated to have higher platelet counts, which may also be secondary to functional asplenia. This appears to be associated with an increased risk of thrombosis, particularly in patients with Blalock-Taussig shunts (subclavian artery to pulmonary artery shunt) [12]. We reviewed our institutional experience with patients with isomerism and functionally univentricular hearts to demonstrate platelet count at various stages of life and identify factors associated with thrombocytosis.

\section{Materials And Methods}

We identified patients with isomerism who were cared for at our institution from January 1998 to January 2014. Data regarding their cardiac and noncardiac anatomy, cardiac surgical palliations, and other findings associated with isomerism were collected by chart review. No patients who had a functionally univentricular heart and isomerism were excluded. Approval for this study was obtained from the Children's Hospital of Wisconsin Institutional Review Board. As this was a retrospective review, a consent waiver was granted for this study.

Cardiac anatomy was analyzed by use of echocardiography although findings were confirmed with catheterization studies, computed tomography, and magnetic resonance imaging when available. This principle of sequential segmental analysis was used to analyze the cardiac anatomy [13]. Bronchial morphology was determined using chest radiographs, computed tomography, and magnetic resonance imaging [14-15]. Intestinal malrotation was assessed by the review of upper gastrointestinal studies. Splenic status was analyzed most often by abdominal ultrasonography, but some patients also had computed tomography or magnetic resonance imaging from which splenic anatomy could also be noted. As it wasn't routine during our study period for the surgeons to document what the atrial appendage morphology was noted to be at the time of surgery and the difficulty associated with imaging the appendages, this data was not available. Instead, we used an aggregate of all the collected features to segregate the entire cohort into having right or left atrial appendage morphology.

Data regarding surgical palliation was obtained from the operative notes. This included the precise procedure, cardiopulmonary bypass time, aortic cross-clamp time, and any operative 


\section{Cureus}

complications. Whether or not patients were extubated in the operating room or not was also noted. The total postoperative length of mechanical ventilation required as well as the need for reintubation in the postoperative period was also collected. The total length of stay associated with surgical palliation was also collected.

Platelet counts were obtained from complete blood counts that are routinely obtained on the day prior to surgery as part of the preoperative assessment. Complete blood counts are also routinely obtained postoperatively and were used for analysis.

The mean platelet count was calculated between birth and first surgical palliation, the day after initial surgical palliation, the day prior to second surgical palliation, the day after second surgical palliation, the day prior to third surgical palliation, and the day after third surgical palliation. Mean platelet count was also calculated at least one year after the third surgical palliation. A student t-test was used to compare mean platelet count between consecutive time points (i.e., before initial surgical palliation and postoperative day 1 after initial surgical palliation). A student t-test was also used to compare mean platelet count at every point to the platelet count before initial surgical palliation.

Thrombocytosis was defined as having a platelet count of $450 \times 10^{9} / \mathrm{L}$. The percent of those having thrombocytosis at each time point was also calculated and compared. A binomial logistic regression was conducted at each time point to determine risk factors for thrombocytosis.

Statistical analysis was done using SPSS version 20.0 (Chicago, IL). A p-value of less than 0.05 was considered statistically significant.

\section{Results}

A total of 57 patients with isomerism and functionally univentricular hearts were included in the analysis. Of these, $54.5 \%$ were male. Cardiac findings included common atrioventricular junction in $68.4 \%$ and double outlet right ventricle in $47.4 \%$. Discordant ventriculoarterial connections were present in $24.6 \%$. Right isomerism was present in $70.2 \%$ and left isomerism in $29.8 \%$. An absence of the spleen was noted in $73.7 \%$, presence of multiple spleens in $14.0 \%$, and the presence of a solitary, normally located spleen in $10.5 \%$ (Table 1).

\section{Characteristic}

Total number

Male

Common atrioventricular junction

Double outlet right ventricle

Double inlet left ventricle

Left sided superior caval vein

Bilateral superior caval veins

Interrupted inferior caval vein

Discordant ventriculoarterial connections

\section{Frequency (Percent) or Median (Minimum to Maximum)} 57

$31(54.5)$

$39(68.4)$

$27(47.4)$

$1(1.8)$

$34(59.6)$

$29(50.9)$

$12(21.1)$

14 (24.6) 


\section{Cureus}

Splenic anatomy

Absence of a spleen

$42(73.7)$

Multiple spleens

$8(14.0)$

Solitary spleen

$6(10.5)$

Data not available

$1(1.8)$

Evaluation for intestinal malrotation

38 (66.7)

Intestinal malrotation

$24(43.9)$

Surgery for intestinal malrotation

$23(40.4)$

Morphology of the atrial appendages by inference

Left

$17(29.8)$

Right

40 (70.2)

Bronchial morphology

Left

5 (8.8)

Right

$45(78.9)$

Imaging not available to determine

Abdominal situs

Right sided liver, left-sided stomach

Left sided liver, right-sided stomach

$13(22.8)$

Midline liver with right or left-sided stomach

$13(22.8)$

Data not available

$4(7.0)$

Arrhythmia

$24(42.1)$

Need for pacemaker

$6(10.5)$

Need for extracorporeal membrane oxygenation

$7(12.3)$

Episode of documented bacteremia

11 (19.3)

Prenatal diagnosis

39 (68.4)

Age at initial surgical palliation $(n=53)$

9 days ( 0 days to 2.7 years)

Age at second surgical palliation $(n=48)$

6.4 months (13 days to 11 years)

Age at third surgical palliation $(n=21)$

3.3 years ( 0.5 years to 15 years)

Mortality

$14(24.6)$

Age at death

3.42 years ( 1 day to 23 years) 


\section{Cureus}

\section{TABLE 1: Overall characteristcs}

Patient characteristics for those included in the analysis

Median age at initial palliation was nine days, the second palliative surgery was at 6.4 months, and the third palliative surgery was at 3.3 years. The mean platelet count before initial surgical palliation was $349.21 \pm 149.28 \times 10^{9} / \mathrm{L}$, with $15.8 \%$ of children having thrombocytosis. The mean platelet count on postoperative day 1 following the initial surgical palliation was $248.63 \pm$ $126.48 \times 10^{9} / \mathrm{L}$. The mean platelet count prior to the second surgical palliation was $422.03 \pm$ $135.54 \times 10^{9} / \mathrm{L}$, with $23.6 \%$ children having thrombocytosis. The mean platelet count on postoperative day 1 following the second surgical palliation was $217.13 \pm 103.74 \times 10^{9} / \mathrm{L}$. The mean platelet count prior to the third surgical palliation was $351.36 \pm 77.79 \times 10^{9} / \mathrm{L}$, with no children having thrombocytosis. The mean platelet count on postoperative day 1 after the third surgical palliation was $180.68 \pm 73.83 \times 10^{9} / \mathrm{L}$. The mean platelet count at the most recent follow-up in patients at least one year removed from the third surgical palliation was $264.12 \pm$ $113.39 \times 10^{9} / \mathrm{L}$, with none having thrombocytosis (Tables $2-4$ ). There was no significant difference in platelet counts between those with right and left isomerism at any stage.

\begin{tabular}{|l|l|l|l|l|l|l|}
\hline $\begin{array}{l}\text { Platelet count } \\
\text { before first } \\
\text { palliation }\end{array}$ & $\begin{array}{l}\text { Platelet } \\
\text { count after } \\
\text { first } \\
\text { palliation }\end{array}$ & $\begin{array}{l}\text { Platelet count } \\
\text { before second } \\
\text { palliation }\end{array}$ & $\begin{array}{l}\text { Platelet count } \\
\text { after second } \\
\text { palliation }\end{array}$ & $\begin{array}{l}\text { Platelet count } \\
\text { before third } \\
\text { palliation }\end{array}$ & $\begin{array}{l}\text { Platelet } \\
\text { count after } \\
\text { third } \\
\text { palliation }\end{array}$ & $\begin{array}{l}\text { Platelet count } \\
\text { late after third } \\
\text { palliation }\end{array}$ \\
\hline $\begin{array}{l}349.21 \pm \\
149.28\end{array}$ & $248.63 \pm$ & $422.03 \pm$ & $217.13 \pm$ & $351.36 \pm$ & $180.68 \pm$ & $264.12 \pm$ \\
\hline $126.48 \dagger$ & $135.54 \dagger$ & $103.74 \dagger$ & $77.79 \dagger$ & $73.83 \dagger$ & $113.39 \dagger$ \\
\hline
\end{tabular}

\section{TABLE 2: Platelet counts}

Mean platelet count for at each time point

†Significant difference between this value and value immediately preceding this

¥Significant difference between this value and the value before stage 1 


\section{Cureus}

\begin{tabular}{|c|c|c|c|}
\hline $\begin{array}{l}\text { No Thrombocytosis Before Initial } \\
\text { Palliation }(n=48)\end{array}$ & $\begin{array}{l}\text { Thrombocytosis Before Initial } \\
\text { Palliation }(n=9)\end{array}$ & $\begin{array}{l}\text { Odds Ratio }(95 \% \\
\text { Confidence Interval) }\end{array}$ & $\begin{array}{l}\mathrm{p}- \\
\text { value }\end{array}$ \\
\hline 34 (70.4) & $4(40.0)$ & 0.281 (0.039 to 2.014$)$ & 0.189 \\
\hline $23(48.1)$ & $3(60.0)$ & $1.615(0.232$ to 11.263$)$ & 0.626 \\
\hline $0(0)$ & $0(0)$ & -- & -- \\
\hline $30(63.0)$ & $1(20.0)$ & 0.147 (0.014 to 1.506$)$ & 0.075 \\
\hline 34 (70.4) & $2(40.0)$ & 0.281 (0.039 to 2.014$)$ & 0.189 \\
\hline 9 (18.5) & $1(20.0)$ & $1.100(0.100$ to 12.087$)$ & 0.938 \\
\hline $11(22.2)$ & $1(20.0)$ & 1.090 (0.084 to 11.457$)$ & 0.908 \\
\hline $12(25.9)$ & $0(0)$ & -- & 0.372 \\
\hline $23(48.1)$ & $3(60.0)$ & 1.615 (0.232 to 11.263$)$ & 0.626 \\
\hline 37 (77.8) 4 (7.4) 7 (14.8) & $5(100.0) 0(0) 0(0)$ & ----- & 0.505 \\
\hline $37(77.8) 11(22.2)$ & $2(40.0) 3(60.0)$ & -- -- & 0.399 \\
\hline
\end{tabular}

\section{TABLE 3: Univariate analysis}

Univariate analysis to idnetify chracteristics associated with thrombocytosis prior to iniital surgical palliation 


\section{Cureus}

\begin{tabular}{|c|c|c|c|}
\hline & $\begin{array}{l}\text { No Thrombocytosis Before } \\
\text { Second Palliation }(n=29)\end{array}$ & $\begin{array}{l}\text { Thrombocytosis Before } \\
\text { Second Palliation }(n=9)\end{array}$ & $\begin{array}{l}\text { Odds Ratio ( } 95 \% \\
\text { Confidence Interval) }\end{array}$ \\
\hline $\begin{array}{l}\text { Atrioventricular septal } \\
\text { defect }\end{array}$ & $19(65.5)$ & $5(55.6)$ & 0.658 (0.144 to 3.013$)$ \\
\hline $\begin{array}{l}\text { Double outlet right } \\
\text { ventricle }\end{array}$ & $17(58.6)$ & $5(55.6)$ & 0.882 (0.195 to 3.987$)$ \\
\hline Double inlet left ventricle & $0(0)$ & $0(0)$ & -- \\
\hline $\begin{array}{l}\text { Bilateral superior caval } \\
\text { vein }\end{array}$ & $15(51.7)$ & $4(44.4)$ & 0.747 (0.166 to 3.357$)$ \\
\hline Left superior caval vein & $18(62.1)$ & $5(55.6)$ & 0.833 (0.164 to 3.425$)$ \\
\hline $\begin{array}{l}\text { Interrupted inferior caval } \\
\text { vein }\end{array}$ & $6(20.7)$ & $1(11.1)$ & 0.479 (0.050 to 4.614$)$ \\
\hline $\begin{array}{l}\text { Discordant } \\
\text { atrioventricular } \\
\text { connections }\end{array}$ & $3(10.3)$ & $3(33.3)$ & 4.34 (0.780 to 6.948$)$ \\
\hline $\begin{array}{l}\text { Discordant } \\
\text { ventriculoarterial } \\
\text { connections }\end{array}$ & $7(24.1)$ & 1 (11.1) & 0.393 (0.046 to 4.214$)$ \\
\hline $\begin{array}{l}\text { Anomalous pulmonary } \\
\text { venous connection }\end{array}$ & $12(43.3)$ & 1 (11.1) & 0.177 (0.024 to 0.956$)$ \\
\hline \multicolumn{4}{|l|}{ Splenic anatomy } \\
\hline Absence of spleen & $19(65.5)$ & $9(100.0)$ & -- \\
\hline Multiple spleens & $5(17.2)$ & $0(0)$ & -- \\
\hline $\begin{array}{l}\text { Solitary, normally located } \\
\text { spleen }\end{array}$ & $5(17.2)$ & $0(0)$ & -- \\
\hline \multicolumn{4}{|c|}{ Atrial appendage morphology } \\
\hline Right & $20(69.0)$ & $7(77.8)$ & -- \\
\hline Left & $9(31.0)$ & $2(22.2)$ & -- \\
\hline
\end{tabular}

\section{TABLE 4: Univariate analysis}

Univariate analysis to identify characteristics associated with thrombocytosis before second palliation

When comparing platelet counts at the various stages to those prior to initial surgical palliation, platelet counts at no subsequent time point differed significantly. When comparing platelet counts at the various stages to the platelet count immediately preceding it, significant differences were noted between all stages and the stage immediately preceding each one. 


\section{Cureus}

Table 5 outlines the platelet count at various stages in those with thrombocytosis prior to initial surgical palliation. Mean platelet count before the initial surgical palliation was $607.40 \pm$ $105.26 \times 10^{9} / \mathrm{L}$ with a decrease in mean platelet count to $288.33 \pm 163.30 \times 10^{9} / \mathrm{L}$ after the third surgical palliation.

\begin{tabular}{|c|c|c|c|c|c|c|}
\hline $\begin{array}{l}\text { Platelet count } \\
\text { before initial } \\
\text { palliation }\end{array}$ & $\begin{array}{l}\text { Platelet } \\
\text { count after } \\
\text { initial } \\
\text { palliation }\end{array}$ & $\begin{array}{l}\text { Platelet count } \\
\text { before second } \\
\text { palliation }\end{array}$ & $\begin{array}{l}\text { Platelet count } \\
\text { after second } \\
\text { palliation }\end{array}$ & $\begin{array}{l}\text { Platelet count } \\
\text { before third } \\
\text { palliation }\end{array}$ & $\begin{array}{l}\text { Platelet } \\
\text { count after } \\
\text { third } \\
\text { palliation }\end{array}$ & $\begin{array}{l}\text { Platelet count } \\
\text { late after third } \\
\text { palliation }\end{array}$ \\
\hline $\begin{array}{l}607.40 \pm \\
105.26\end{array}$ & $\begin{array}{l}331.20 \pm \\
125.14 \dagger\end{array}$ & $\begin{array}{l}452.20 \pm \\
122.63\end{array}$ & $\begin{array}{l}193.00 \pm \\
81.25 \dagger\end{array}$ & $\begin{array}{l}355.67 \pm \\
83.20 \dagger\end{array}$ & $\begin{array}{l}196.33 \pm \\
40.15\end{array}$ & $288.33 \pm 163.30$ \\
\hline
\end{tabular}

\section{TABLE 5: Platelet counts}

Mean platelet count at each time for those who had thrombocytosis prior to initial surgical palliation

†Significant difference between this value and value immediately preceding this

$\ddagger$ Significant difference between this value and the value before Stage 1

Univariate analysis of those with and without thrombocytosis before initial surgical palliation did not identify any particular cardiac anomalies, splenic anatomy, or isomerism sidedness as being associated with increased risk of thrombocytosis. Multivariate analysis demonstrated similar findings. Univariate analysis of those with and without thrombocytosis before the second surgical palliation identified discordant atrioventricular connections as being associated with thrombocytosis, with an odds ratio of 4.34 . This did not remain significant in the multivariate analysis.

\section{Discussion}

Platelet counts are dynamic in children with functionally univentricular hearts and isomerism. This is not unexpected as these children undergo multiple procedures early in life, which in and of itself, can lead to changes in platelet count. What is unique to the isomerism population, however, is the increased risk of thrombocytosis. We demonstrated a $15.8 \%$ frequency of thrombocytosis before the initial surgical palliation and $23.6 \%$ before the second surgical palliation. No thrombocytosis was noted after the second surgical palliation.

No anatomic features could be identified as being predictive of thrombocytosis before the initial surgical palliation. Those with discordant atrioventricular connections tended to have an increased likelihood of thrombocytosis before the second surgical palliation, although this no longer remained significant after multivariate analysis.

In both the overall cohort, as well as only those with thrombocytosis before initial surgical palliation, there was an overall negative trend in the platelet count from prior to initial surgical palliation to after the third surgical palliation, although this was not statistically significant.

None of the anatomic characteristics studies were found to be predictive of thrombocytosis prior to initial surgical palliation. Prior to the second surgical palliation, however, discordant 
atrioventricular connections were an univariate predictor of thrombocytosis, although no multivariate predictors were identified.

Thrombocytosis in these children is of particular consequence as it has been demonstrated to increase the risk of aortopulmonary shunt thrombosis, a risk primarily noted with the BlalockTaussig shunt. There is an increase in the risk of shunt thrombosis in children with functionally univentricular hearts who also have isomerism. This is particularly notable in those who have the absence of a spleen as well [12]. This risk has not been noted with the right ventricle to pulmonary artery conduits, and thus, the presence of thrombocytosis prior to initial surgical palliation should warrant increased consideration of the placement of a right ventricle to pulmonary artery shunt rather than a Blalock-Taussig shunt at the time of the initial surgical palliation.

Yamamura and colleagues demonstrated higher platelet counts in those with the absence of a spleen versus those with a spleen. The risk of thrombosis was also greater in those with an anatomic absence of the spleen [12]. It is important to note that those with isomerism and the presence of multiple spleens or a solitary, normally located spleen may also have functional asplenia, and thus, the anatomic splenic status may not be the ideal factor to use in such studies [11]. Splenic function based on Howell-Jolly bodies or pitted red blood cell counts would be the more appropriate factor to use. Our current study is limited by this as well as it had not previously been routine practice to assess splenic function. It would be prudent to routinely assess splenic function by means of either of the two aforementioned tests in all patients with isomerism for both evaluation of their infectious risk as well as to correlate with potential thrombocytosis.

The time course of thrombocytosis noted in those with isomerism is consistent with that found in those with functional asplenia due to other causes, such as sickle cell disease [16-17]. Splenectomy has been noted to be one of the main causes of reactive thrombocytosis. Postsplenectomy, platelet counts generally peak between postoperative day 7 and 20 and then return to normal within weeks or months, rarely taking years to normalize [16, 18].

It has now been demonstrated that at least $40 \%$ of those with isomerism will have ciliary dyskinesia [19]. In those with isomerism, the cilia often have normal ultrastructure but have an abnormal beating pattern and frequency, which compromises their function. Once thought to serve a mechanical function for moving fluids and other material, it is now understood that cilia also play a role in mechanosensory transduction [20]. Found in almost every tissue type, the role of cilia in several organs is still not well understood. Splenic tissue does contain cilia, and it is quite possible that functional asplenia present in the setting of a solitary spleen or multiple spleens may be the underlying mechanism of the abnormal function [20-22]. Whether this is due to alteration of a mechanical or sensory ciliary function is not clear.

This study is limited by its small sample size. Multivariate analysis is not highly powered due to this. Additionally, as there is variability in the underlying cardiac anatomy, not all patients underwent the same surgical palliation in the same order. Thus, those with hypoplastic left heart syndrome may have undergone a Norwood, Glenn, and Fontan operation while a child with double outlet right ventricle with pulmonary stenosis may have undergone Glenn and Fontan, not requiring an initial Norwood operation. This would explain why the ages of the initial, second, and third surgical palliations do not necessarily coincide with ages of the Norwood, Glenn, and Fontan that are generally seen. Nonetheless, this study does provide some insight into this phenomenon in a particularly vulnerable population while underscoring the need for larger studies, which would be best served by a multicenter approach.

\section{Conclusions}


Thrombocytosis is not uncommon in the first year of life in those with isomerism and a functionally univentricular heart. Platelet counts decrease from birth onwards, however, and thrombocytosis at long-term follow-up after a third surgical palliation is uncommon. Independent risk factors for thrombocytosis could not be identified.

\section{Additional Information}

\section{Disclosures}

Human subjects: Consent was obtained by all participants in this study. Children's Hospital of Wisconsin issued approval N/A. Animal subjects: All authors have confirmed that this study did not involve animal subjects or tissue. Conflicts of interest: In compliance with the ICMJE uniform disclosure form, all authors declare the following: Payment/services info: All authors have declared that no financial support was received from any organization for the submitted work. Financial relationships: All authors have declared that they have no financial relationships at present or within the previous three years with any organizations that might have an interest in the submitted work. Other relationships: All authors have declared that there are no other relationships or activities that could appear to have influenced the submitted work.

\section{References}

1. Evans WN, Acherman RJ, Restrepo H: Heterotaxy in southern Nevada: prenatal detection and epidemiology. Pediatr Cardiol. 2015, 36:930-34. 10.1007/s00246-015-1099-3

2. Lopez KN, Marengo LK, Canfield MA, Belmont JW, Dickerson HA: Racial disparities in heterotaxy syndrome. Birth Defects Res A Clin Mol Terato. 2015, (Epub ahead of print):10.1002/bdra.23416

3. Lin AE, Krikov S, Riehle-Colarusso T, Frías JL, Belmont J, Anderka M, Geva T, Getz KD, Botto LD, National Birth Defects Prevention Study: Laterality defects in the national birth defects prevention study (1998-2007): birth prevalence and descriptive epidemiology. Am J Med Genet A. 2014, 164A:2581-91. 10.1002/ajmg.a.36695

4. Loomba RS, Hlavacek AM, Spicer DE, Anderson RH: Isomerism or heterotaxy: which term leads to better understanding?. Cardiol Young. 2015, 25:1037-43.

10.1017/S1047951115001122

5. Loomba R, Shah PH, Anderson RH: Fetal magnetic resonance imaging of malformations associated with heterotaxy. Cureus. 2015, 7:e269. 10.7759/cureus.269

6. Jacobs JP, Anderson RH, Weinberg PM, Walters HL 3rd, Tchervenkov CI, Del Duca D, Franklin RC, Aiello VD, Béland MJ, Colan SD, Gaynor JW, Krogmann ON, Kurosawa H, Maruszewski B, Stellin G, Elliott MJ: The nomenclature, definition and classification of cardiac structures in the setting of heterotaxy. Cardiol Young. 2007, 17:1-28. 10.1017/S1047951107001138

7. Uemura H, Ho SY, Devine WA, Kilpatrick LL, Anderson RH: Atrial appendages and venoatrial connections in hearts from patients with visceral heterotaxy. Ann Thorac Surg. 1995, 60:56169. 10.1016/0003-4975(95)00538-V

8. Smith A, Ho SY, Anderson RH, Connell MG, Arnold R, Wilkinson JL, Cook AC: The diverse cardiac morphology seen in hearts with isomerism of the atrial appendages with reference to the disposition of the specialised conduction system. Cardiol Young. 2006, 16:437-54. 10.1017/S1047951106000382

9. Loomba RS, Willes RJ, Kovach JR, Anderson RH: Chronic Arrhythmias in the Setting of Heterotaxy: Differences between Right and Left Isomerism. Congenital heart disease. Congenit Heart Dis. 2015, (Epub ahead of print):10.1111/chd.12288

10. Loomba RS, Aggarwal S, Gupta N, Buelow M, Alla V, Arora RR, Anderson RH: Arrhythmias in adult congenital patients with bodily isomerism. Pediatr Cardiol. 2015, (Epub ahead of print):1-8. 10.1007/s00246-015-1281-7

11. Nagel BH, Williams H, Stewart L, Paul J, Stümper O: Splenic state in surviving patients with visceral heterotaxy. Cardiol Young. 2005, 15:469-73. 10.1017/S1047951105211320

12. Yamamura K, Joo K, Ohga S, Nagata H, Ikeda K, Muneuchi J, Watanabe M, Hara T: Thrombocytosis in asplenia syndrome with congenital heart disease: a previously 
unrecognized risk factor for thromboembolism. Int J Cardiol. 2013, 167:2259-63.

10.1016/j.ijcard.2012.06.009

13. Anderson RH, Becker AE, Freedom RM, Macartney FJ, Quero-Jimenez M, Shinebourne EA, Wilkinson JL, Tynan M: Sequential segmental analysis of congenital heart disease . Pediatr Cardiol. 1984, 5:281-87. 10.1007/BF02424973

14. Loomba RS, Pelech AN, Shah PH, Anderson RH: Determining bronchial morphology for the purposes of segregating so-called heterotaxy. Cardiol Young. 2015, (Epub ahead of print):113. Accessed: October 31, 2015: http://journals.cambridge.org/action/displayAbstract? fromPage $=$ online \&aid=9845993 \& fileId=S1047951115001195. 10.1017/S1047951115001195

15. Partridge JB, Scott O, Deverall PB, Macartney FJ: Visualization and measurement of the main bronchi by tomography as an objective indicator of thoracic situs in congenital heart disease. Circulation. 1975, 51:188-96. 10.1161/01.CIR.51.1.188

16. Khan PN, Nair RJ, Olivares J, Tingle LE, Li Z: Postsplenectomy reactive thrombocytosis. Proc (Bayl Univ Med Cent). 2009, 22:9-12.

17. Buss DH, Cashell AW, O'Connor ML, Richards F 2nd, Case LD: Occurrence, etiology, and clinical significance of extreme thrombocytosis: a study of 280 cases. Am J Med. 1994, 96:24753. 10.1016/0002-9343(94)90150-3

18. Chanet V, Tournilhac O, Dieu-Bellamy V, Boiret N, Spitz P, Baud O, Darcha C, Travade P, Laurichesse $\mathrm{H}$ : Isolated spleen agenesis: a rare cause of thrombocytosis mimicking essential thrombocythemia. Haematologica. 2000, 85:1211-13.

19. Nakhleh N, Francis R, Giese RA, Tian X, Li Y, Zariwala MA, Yagi H, Khalifa O, Kureshi S, Chatterjee B, Sabol SL, Swisher M, Connelly PS, Daniels MP, Srinivasan A, Kuehl K, Kravitz N, Burns K, Sami I, Omran H, Barmada M, Olivier K, Chawla KK, Leigh M, Jonas R, Knowles M, Leatherbury L, Lo CW: High prevalence of respiratory ciliary dysfunction in congenital heart disease patients with heterotaxy. Circulation. 2012, 125:2232-42. 10.1161/CIRCULATIONAHA.111.079780

20. D'Angelo A, Franco B: The primary cilium in different tissues-lessons from patients and animal models. Pediatr Nephrol. 2011, 26:655-62. 10.1007/s00467-010-1650-7

21. Loomba RS, Anderson RH: Letter to the editor regarding "Situs inversus with levocardia, infrahepatic interruption of the inferior vena cava, and azygos continuation: a case report". Surg Radiol Anat. 2015, Epub ahead of print:10.1007/s00276-015-1492-X

22. Abdel-Bari W, Sorenson GD: Ciliated cells in the spleen of adult rats . Anat Rec. 1965, 152:481-85. 10.1002/ar.1091520407 